African Journal of Sustainable Agricultural Development | ISSN: 2714-4402

Vol. 1, Number 4 (October-December, 2020)| www.ijaar.org/ajsad

Journal DOI: 10.46654/2714

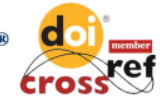

Article DOI: 10.46654/2714.14127

\title{
ANALYSIS OF USE OF AGRO-CHEMICALS AMONG VEGETABLE FARMERS IN MAIDUGURI AND ITS ENVIRONS, NIGERIA
}

\author{
Mustapha, S. B. \\ Department of Agricultural Extension Services, \\ University of Maiduguri, Nigeria \\ Email: sbmustapha@unimaid.edu.ng \\ Mobile Phone: $+234(0) 7060573884$
}

\begin{abstract}
The study analysed the use of agro-chemicals among vegetable farmers in Maiduguri and its environs in Nigeria. Primary data were mainly used for the study. Multi - stage sampling techniques was employed to select 160 vegetable farmers for this study. Both descriptive (frequency distribution, percentages and mean scores) and inferential (regression analysis) statistics were used to analyze the data. The studies revealed that majority (77.50\%) of the respondents were male and married (85.63\%). The results indicated that majority (70.0\%) of the respondents had 7 and above years of formal education. On the vegetable farmer's sources of information on agro-chemical usage, the study revealed that most (50\%) of the respondents got information on agrochemicals from other farmers, followed by stockists with 20\%. Most (36.80\%) of the respondents showed that they make use of herbicides than other forms of agrochemicals. The farm size ( $\mathrm{ha}$ ) and income of the respondents has a positive and significant coefficient with $p$ values of 0.000 at $1 \%$ level each. The major constraints considered as severe on the use of agro-chemicals among the respondents were high cost of supplies (mean score = 2.16), irregular supplies and insufficient farm incomes (mean score $=2.10$ ) each which were ranked $1^{\text {st }}$ and $2^{\text {nd }}$ respectively. The study recommended those agricultural extension organizations and other stakeholders such as the Ministry of agriculture to carry out improved mobilization and sensitization campaigns to educate farmers on proper and efficient use of agrochemicals with a view to improving productivity as well as prevent adverse environmental and human health effects.
\end{abstract}

Key Words: Analysis, Utilization, Agro-chemicals, Vegetable farmers, Environs 


\section{INTRODUCTION}

Vegetables are the most important ingredients of human diets for the maintenance of good health and prevention of diseases (Funmilayo et al., 2016). Cultivation of vegetables is an excellent source of employment for both rural and urban dwellers as it takes place in many rural areas through truck farming and in the outskirts of towns and cities in the form of market and backyard gardening to supply fresh produce to urban markets (Afari-Sefa et al., 2015). It thus, plays an important socioeconomic role as well as in diversifying diets for improved nutrition (Ntow et al., 2006; Matthews, 2008). As vegetables are generally susceptible to a wide range of pests and diseases, these are major constraints to vegetable production in Nigeria and require intensive effort in their management (Maisamari, 2001). The increased demand for food, particularly to feed the growing urban population in Nigeria has necessitated an expansion and intensification of agriculture and horticulture and a concomitant increase in the use of synthetic agro-chemicals for food production, particularly for the production of high-value cash crops and vegetables (Jamala et al., 2013). However, these agrochemicals are often applied indiscriminately and inappropriately, resulting in adverse environmental and health effects.

Agro-chemicals refers to the broad range of pesticides and insecticides including fertilizers, hormones, herbicides, fungicides, and other growth chemicals and concentrated stores of raw animal manure (cow dung and poultry droppings) (Ngowi1 et al., 2007). Globally, agro-chemicals are used for improving soil fertility and productivity. According to Alex (2007), the continuous use of agro-chemicals is dangerous to the health of both the soil and humans. Agro-chemicals are expensive and unaffordable by many small-scale farmers. Many agro-chemicals are toxic and agro-chemicals in bulk storage may pose a significant environmental and/or health risks particularly in the event of accidental spills (Andrew, 2007). The use of these agro-chemicals though on one side accounts for increased yield, on the other hand, the products are of less natural content and contain some heavy chemicals. These agrochemicals to some extent proved harmful not only for humans but also pose a great danger to the environment. Fleisher (2006), reported that the use of synthetic fertilizers and pesticides in the developing countries has grown substantially during the past four decades. Government promotes the use of agro-chemicals in order to achieve national food security and improve the production of export crops.

Good management and proper disposal of agro-chemicals is an important health and environmental issues in the developing countries (WHO, 2012). The total exposure to the chemicals is the sum of exposure during agro-chemicals storing, mixing, applying and disposing (Bhandari et al., 2020). These agro-chemicals are inhaled through different routes via; oral (through the mouth and digestive system), dermal (through the skin), occularly (through eyes) or by inhalation (through the nose and respiratory system). Agro-chemicals could have effect on the decline of biodiversity by indirect effect to the nontarget organisms. Knowledge of existing relationship between agro-chemicals input usage and vegetable production would provide a basis for favorable policies on agro-chemicals input promotion so as to enhance its accessibility to smallholder farmers. It is also possible that certain socio-economic factors affect agro-chemicals input usage among the vegetable farmers. Scientific information on the possible constraints to the use of agro-chemicals by vegetable farmers would provide insight for 


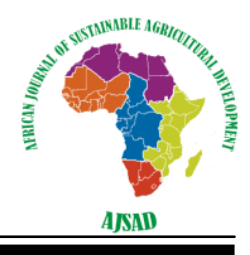

decision making on best ways of enhancing its use among vegetable farmers in the study area. The specific objectives of this study were to: -

(i) identify the socio-economic characteristics of vegetable farmers in the study area;

(ii) establish the source of information on the use of agrochemicals among vegetable farmers;

(iii) ascertain the most utilized agro-chemicals among the respondents;

(iv) determine the influence of socio-economic- factors on agro-chemicals usage among respondents; and

(v) investigate the constraints to improved use of agro-chemicals among the respondents.

\section{METHODOLOGY}

The study was conducted in Maiduguri and its environs, Borno State, Nigeria, which is located in the extreme north-east corner of Nigeria. The Maiduguri Metropolis is made up with some parts of Jere, Konduga and Mafa Local Government Areas. Maiduguri Metropolis has a population density of 1,738 people per square kilometer, which lies between latitudes $11^{\circ} .83^{\prime}$ North of the equator and longitudes 130.501 East of the Greenwich Meridian (BOSADP, 2003). The hottest period is between March and May with $44.4^{\circ} \mathrm{C}$, while, the coldest Month is January, with $12.6^{\circ} \mathrm{C}$ (Daura, 2001). Agriculture is the main stay of the economy of Maiduguri and its environs, Borno State and vegetables (onion, pepper, tomatoes etc) are one of the major crops produced in the area.

Primary data was generated from vegetable farmers through the use of structured and pre- tested interview schedules. Interview schedules were employed as a result of the assumed low level literacy of the respondents. These were administered by enumerators who were trained for this purpose under the supervision of the researcher. In some instances, discussion with key informants and experts were held. Secondary information from Area Extension Officers (AEOs) of BOSADP was used to complement the primary data. Other sources of secondary information include: research reports, government publications, textbooks, journal publications and other write-up that are relevant to this study.

Multi - stage sampling techniques was employed to select the respondents for this study. The first stage of the sampling was purposive selection of four (4) wards based on the predominance of vegetable farming. At the second stage, three (2) vegetable associations were selected at random from each of the wards to be sampled. A simple random sample gives each household in the area under study an equal chance of being selected, and study findings could be fairly generalised across the study population. At the third stage, 20 respondents were proportionately selected from each of the selected vegetable associations. Therefore, 160 respondents were used for the study. The lists of the communities and vegetable farmers were obtained from BOSADP for this research project.

Descriptive statistics was used to analyze the data collected for this study. These were used to achieve the specific objectives of the study. Descriptive statistics such as frequencies, percentages and mean scores were used to achieve objectives (i), (ii) and (iii).

A three point Likert-type scale was used to elicit information on the extent to which the respondents considered specific constraints to their improved usage of agro-chemicals. A list of possible constraints 
drawn from literature was presented against which the farmers responded as to their severity of constraint using the Likert-type scale graduated thus; Mild constraint $=1$, severe constraint $=2$ and very severe constraint $=3$. The mean score was obtained for each constraints and that was used to rank the constraints in order of severity (specific objective v).

\section{Key}

Mild constraint $=2.0$ and above

Severe constraint $=$ Less than 2.0

The regression analysis was used to determine the factors influencing agro-chemical usage in vegetable production among the respondents (specific objective iv). The regression model in its explicit form is given as;

$Y=f\left(X_{1}, X_{2}, X_{3}, X_{4}, X_{5}, X_{6}, X_{7}, U\right)$.

Where:

$\mathrm{Y}=$ Investment in agro-chemicals input used measured in Naira (

$\mathrm{X}_{1}=$ Farm Size measured in hectares

$\mathrm{X}_{2}=$ Total Income measured in naira as the addition of farm income, non farm income and available income from other household members

$\mathrm{X}_{3}=$ Age measured in years

$\mathrm{X}_{4}=$ Highest Educational Attainment measured as a dummy variable; 1 for the possession of formal education and 0 otherwise

$\mathrm{X}_{5}=$ Gender measured as a dummy variable; 1 for male and 0 for female

$\mathrm{X}_{6}=$ Farming Experience measured as number of years spent in vegetable farming

$\mathrm{X}_{7}=$ Household size measured as the number of persons living under the same roof and eating from the same pot

$\mathrm{U}=$ Error term

\section{RESULTS AND DISCUSSION}

\section{Socio-Economic Characteristics of Respondents}

The socio-economic characteristics of the respondents are presented under this section. The socioeconomic variables studied include sex, marital status, age, household size, formal education, size of farmland of the respondents (Table 1). 


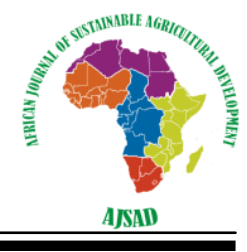

Table 1: Distribution of respondents by socio - economic characteristics $(n=160)$

\begin{tabular}{|c|c|c|}
\hline Socio - economic characteristics & Frequency & Percentage \\
\hline \multicolumn{3}{|l|}{ Sex } \\
\hline Male & 124 & 77.50 \\
\hline Female & 36 & 22.50 \\
\hline \multicolumn{3}{|l|}{ Marital status } \\
\hline Married & 137 & 85.63 \\
\hline Single & 23 & 14.37 \\
\hline \multicolumn{3}{|l|}{ Age (years) } \\
\hline Less than 21 & 19 & 11.87 \\
\hline $21-30$ & 29 & 18.13 \\
\hline $31-40$ & 48 & 30.00 \\
\hline $41-50$ & 48 & 30.00 \\
\hline 51 and above & 16 & 10.00 \\
\hline \multicolumn{3}{|l|}{ Household size (No.) } \\
\hline Less than 5 & 20 & 12.50 \\
\hline $5-8$ & 30 & 18.80 \\
\hline $9-12$ & 50 & 31.20 \\
\hline $13-16$ & 46 & 28.75 \\
\hline 17 and above & 14 & 08.75 \\
\hline \multicolumn{3}{|l|}{ Formal education (years) } \\
\hline None & 20 & 12.50 \\
\hline $1-6$ & 28 & 17.50 \\
\hline $7-12$ & 57 & 35.60 \\
\hline 13 and above & 55 & 34.40 \\
\hline \multicolumn{3}{|l|}{ Size of farmland (ha) } \\
\hline Less than 0.5 & 41 & 12.80 \\
\hline $0.5-1.0$ & 58 & 18.10 \\
\hline $1.1-1.5$ & 95 & 29.70 \\
\hline $1.6-2.0$ & 93 & 29.10 \\
\hline above 2.0 & 33 & 10.30 \\
\hline
\end{tabular}

\section{Source: Field survey; 2018}

Sex: The studies revealed that majority $(77.50 \%)$ of the respondents were male, while only $22.50 \%$ of them were female. The most probable reason for such overwhelming majority of male vegetable farmers were that the male farmers constituted the household heads who responded on behalf of the households except in a situation where the household head was a female. The fact that majority of the respondents were male implies that majority of them might have better access to extension contact and other necessary farm technologies. This is in agreement with that of Onu (2006), who reported that sex plays significant role in having access to production resources, and hence utilization of agricultural technologies such as agro-chemicals. He affirmed that activities of women farmers are faced with 


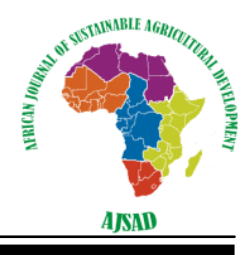

socio-cultural restrictions. In Sub-Saharan Africa, conventional methods of agricultural extension have traditionally tended to be geared towards men while, ignoring women (Idrisa et al, 2007). Extension messages are generally provided by male extension agents to men with the implicit assumption that such message will "trickle down" to women. This situation normally results in differential access to and control over land use right and other production technologies between male and female farmers.

Marital Status: Table 1 revealed that majority (85.63\%) of the respondents were married, while only $14.37 \%$ of them were single. Marital status has implication for adoption of improved agricultural technologies such as agrochemicals. The married farmers could have more responsibilities and hence they tend to take whatever they do with higher level of seriousness. In that case, they could be willing to utilize improved technologies such as agro-chemicals so as to improve the living standards of their family. On the other hand, unmarried or single farmers might not have all the seriousness deserved to utilize improved technologies for the betterment of their living standards. Marital status has implication for utilization of agricultural technologies such as agro-chemicals (Idrisa et al, 2007). On the other hand, especially, with regards to female, being married could be a serious hindrance to accessibility of and utilization of improved agricultural technologies, more especially in the study area where culture restricts interaction between other males and females.

Age: Table 1 revealed that $11.87 \%$ of the respondents were less than 21 years of age, $18.13 \%$ of the respondents were within the age bracket of 21-30 years, while $10.0 \%$ of the respondents were above 51 years of age. Moreover, approximately $60 \%$ of the respondents were 40 years old or younger. By implication, the study area has large number of young farmers who have the potentials for the utilization of improved agricultural technologies such as agro-chemicals. This is because they are relatively more open to risk taking and have longer planning horizon (Benedicta, 2010).

Household Size: Table 1 showed that $12.50 \%$ of the respondents had household size of less than 5 members, while $8.75 \%$ of the respondents had household size of 17 and above members. However, most $(50 \%)$ of the respondents had household size of 9-16 members. Household forms the main source of labour in African agriculture. The need for family labour could be more where farming activities relating to the technology in question are labour-intensive and where the farmers are basically subsistent. The subsistence nature of the farmers does not leave them with enough capital to re-invest in their farming activities, and the need for labour could be high throughout the production period. This could inform the need for labour from family source. Hence the capacity of households to supply labour greatly influences the level of utilization of agricultural technologies such as agro-chemicals. This is mainly as a result of the fact that the subsistence farm households are resource - poor and might have to depend on family labour for agricultural activities which in most instances is labour intensive (Idrisa et al., 2007).

Formal Education: Table 1 also revealed the years spent in formal education. The study showed that $12.50 \%$ of the respondents had no formal education, $17.50 \%$ of them had 1-6 years of formal education, $35.60 \%$ of them had 7-12 years and 34.40\% of them had 13 and above years of formal education. The results indicated that majority (70.0\%) of the respondents had 7 and above years of formal education, indicating that the respondents were literate with a good number of them having at 


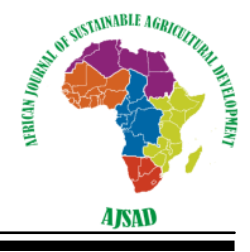

least 7 years of formal education. The high level of formal education in the study area could mean that majority of the farmers were expected to utilize agricultural technologies such as agro-chemicals within a relatively shorter period of time. This is in line with the findings of Idrisa (2009) where the study reported $75 \%$ literacy level among soya bean farmers in Borno state, Nigeria.

Farm Size: The farm size distribution of respondents is presented in Table 1. The result showed that majority $(58.80 \%)$ of the respondents devoted 1.1 to 2.0 of farmland to food crop production during the vegetable cropping season under study. Vegetable farmers who possess a relatively large farm holding were more resource - endowed and therefore were more likely to have the required resources necessary for the acquisition of and use of improved technologies (Idrisa et al., 2007). This puts them at an advantage position to utilize improved agricultural technologies compared to farmers who have smaller vegetable farm holdings. On the other hand, vegetable farmers operating on smaller farm holdings are placed at a disadvantaged position because of fragmentation (World Bank, 2008).

\section{Sources of Information on the Use Agrochemicals among Respondents}

Table 2 presented the various sources of information on the use of agro-chemicals in the study area. These are described as follows.

$\begin{array}{llc}\begin{array}{l}\text { Table 2: Sources of information on the use of agrochemicals among respondents } \\ \text { Farmers primary source of knowledge }\end{array} & \text { Frequency (No.) } & \begin{array}{c}\text { Percentage (\%) } \\ \text { Agrochemical stockists }\end{array} \\ \text { Agricultural extension agents } & 25 & 20.00 \\ \text { Other Farmers } & 80 & 15.62 \\ \text { Radio } & 13 & 50.00 \\ \text { Television } & 6 & 8.13 \\ \text { Researchers } & 4 & 3.75 \\ \text { Total } & \mathbf{1 6 0} & 2.50 \\ \end{array}$

Source; Field survey, 2018

On the vegetable farmer's sources of information on agro-chemical usage, the study revealed that most $(50 \%)$ of the respondents got information on agrochemicals from other farmers, followed by stockists with $20 \%$. The agricultural extension agents represented $15.62 \%$. The researchers represented only $2.5 \%$ only. The study indicated that respondents got information on agro-chemicals mainly from among themselves is of concern as there is no guarantee on the quality the information disseminated. The result revealed that other farmers were major source of information. Other sources such as the other farmers and agro-chemical stockists would have been much more concerned with making money from their sales rather than disseminating information to farmers on proper handling of agrochemicals. The study indicated that the extension agents played an insignificant role in the dissemination of information on agro-chemical usage and precautionary measures. The implication could be that the reliance on informal information sources could be attributed to inadequate agricultural extension services. 


\section{Most Utilized Agro-chemicals among Respondents}

Table 3 shows the distribution of respondents according to the most utilized agro-chemicals in the study area. Most $(36.80 \%)$ of the respondents showed that they make use of herbicides than other forms of agro-chemicals. This implies that they use herbicides to complement the labour requirement in vegetable farming. The use of fertilizer and pesticides represented $32.10 \%$ and $25.8 \%$ respectively. This agrees with the findings of Ngowil et al. (2007) who posited that application of fertilizer and pesticides increased crop yield. The fungicides are the least utilized agro-chemicals among the respondents in the study area. This could be attributed to low incidence of diseases affecting the vegetable farms in the study area.

\begin{tabular}{lcc} 
Table 3: Distribution of Respondents According to Most Utilized Agro-Chemicals \\
Agro-chemicals & Frequency (No.) & Percentage (\%) \\
Fertilizer & 51 & 32.10 \\
Herbicides & 59 & 36.80 \\
Pesticides & 41 & 25.80 \\
Fungicides & 9 & 5.30 \\
Total & $\mathbf{1 6 0}$ & $\mathbf{1 0 0 . 0 0}$ \\
\hline
\end{tabular}

\section{Source; Field survey, 2018}

\section{Socio-economic Factors Influencing the Utilization of Agro-chemicals among Respondents}

This sub-section determined the factors influencing the agro-chemical input use among vegetable farmers in the study area. Table 4 presents the result of the linear regression analysis carried out to establish the socio-economic factors that influenced the utilization of agro-chemicals among the respondents. To determine the factors influencing agro-chemical inputs use in vegetable production, regression model was fitted that determined the effect of some independent variables on the investment in agro-chemicals use. The coefficient of determination $\left(\mathrm{R}^{2}\right.$ adjusted) with value 0.738 showed that the explanatory variables explained about $73.8 \%$ of the variations in the use of agro-chemical inputs on the vegetable farms leaving about $26.2 \%$ only un-explained.

Table 4: Regression Results of Factors Influencing the Utilization of Agro-chemicals among Vegetable Farmers

\begin{tabular}{|l|l|l|}
\hline Variables & Co-efficient & p-value \\
\hline Constant & 14413.952 & 0.423 \\
\hline Farm Size & $7978.215^{* * *}$ & 0.000 \\
\hline Income & $0.050^{* * *}$ & 0.000 \\
\hline Age & 0.991 & 0.865 \\
\hline Education & $2.690^{*}$ & 0.045 \\
\hline Gender & 1.079 & 0.813 \\
\hline Farming Experience & -18.895 & 0.787 \\
\hline Household Size & $-810.053^{*}$ & 0.084 \\
\hline
\end{tabular}

Source; Field survey, 2018

$* * *(\mathrm{p}<0.01) ; *(\mathrm{p}<0.1)$

$\mathrm{R}^{2}=0.735$, Adjusted $\mathrm{R}^{2}=0.738$ 
Table 4 showed the effect of each independent variable on the dependent variable (investment on agrochemical use). The farm size (ha) has a positive and significant coefficient with p value of 0.000 at $1 \%$ level. This result implied that if the farm size is increased by a unit measure, the investment on chemical input use will increase by 1 unit. Another factor with significant effect on the investment of chemical input use was income of the farmers. The variable also had a coefficient with value of 0.00 . This was also significant at $\alpha=1.0 \%$. This implies that if the farmers' income increased by $\$ 1.00$, the investment on chemical use by the farmers will increase by 1 unit. The coefficient of highest educational attainment was also found to be significant at $\alpha=5 \%$, meaning that the more educated the farmers were, the more their chances of investing in the use of agrochemicals. This is likely due to the established relationship between education and the rate of adoption of agricultural technologies. The household size with coefficient of -810.053 was however found to be though significant, inversely related to investment in agro-chemical input use. An increase in household size therefore will result in a reduction in agro-chemical input use. It is possible that high household size presents a drain on the family income and hence a reduction in the available income to procure agro-chemical. The large family size could also provide the necessary manpower to carry out manual weeding as opposed to the use of herbicides.

\section{Constraints to Utilization of Agro-chemicals among Respondents}

This sub-section analyzed the constraints to the improved use of agro-chemical inputs among vegetable farmers in the study area. Table 5 presents the major constraints to improved use of agrochemicals which ranked the constraints in order of severity. The major constraints considered as severe on the use of agro-chemicals among the respondents were high cost of supplies (mean score $=2.16$ ), irregular supplies and insufficient farm incomes (mean score $=2.10$ ) each which were ranked $1^{\text {st }}$ and $2^{\text {nd }}$ respectively. Other constraints considered to be mild on the use of agro-chemicals among the respondents were large farm size (mean score $=1.90$ ), long distance from source (mean score $=1.77$ ), health hazards (mean score $=1.71$ ) and poor knowledge of application (mean score $=1.42$ ) which were ranked $4^{\text {th }}, 5^{\text {th }}, 6^{\text {th }}$ and $7^{\text {th }}$ respectively.

Table 5: Major Constraints to Improved Use of Agro-Chemicals among Respondents

\begin{tabular}{|l|l|l|}
\hline Agro-chemicals & Mean Scores & Rank \\
\hline High cost of supplies & 2.16 & $1^{\text {st }}$ \\
\hline Irregular supplies & 2.10 & $2^{\text {nd }}$ \\
\hline Poor farm income & 2.10 & $2^{\text {nd }}$ \\
\hline Large farm size & 1.90 & $4^{\text {th }}$ \\
\hline Long distance from source & 1.77 & $5^{\text {th }}$ \\
\hline Health hazard & 1.71 & $6^{\text {th }}$ \\
\hline Poor knowledge of application & 1.42 & $7^{\text {th }}$ \\
\hline
\end{tabular}

Source; Field survey, 2018

\section{KEY}

Mild constraint $=2.0$ and above

Severe constraint $=$ Less than 2.0 


\section{CONCLUSION AND RECOMMENDATIONS}

Improved usage of agro-chemicals constitutes a significant aspect of improved vegetable farmer productivity. Based on the findings of the study, majority of the respondents were relatively young, thus economically active on vegetable farming activities. About half had 7 and above years of formal education. The study concluded that farm size, education and incomes of the respondents were the major factors influencing the use of agro-chemicals in the study area. The respondent's usage of the agro-chemicals was constrained by high cost of supplies, irregular supplies and insufficient farm incomes. Based on the major findings of the study and the conclusions reached, the following recommendations were made:

i. Agricultural extension organizations and other stakeholders such as the Ministry of Agriculture to carry out improved mobilization and sensitization campaigns to educate farmers on proper and efficient use of agro-chemicals with a view to improving productivity as well as prevent adverse environmental and human health effects. This should involve safety precautions on mixing, spraying and disposing spoilt and expired chemicals as well as empty agrichemical containers so as to prevent endangering other persons and children.

ii. There should be developed proper and effective information dissemination channels to ensure that farmers have adequate sources of technical information available on the safe use of the agro-chemicals with regard to their recommended usage, human health and the environment.

\section{Acknowledgement}

The financial support of the Tertiary Education Trust Fund (tetfund) in carrying out this study is gratefully acknowledged. We would also like to thank the vegetable farmers and extension staff in the study areas for their good cooperation during the course of the study, and lastly research assistants for their active participation in data collection for this research study. 


\section{REFERENCES}

Afari-Sefa, V., Asare-Bediako, E., Kenyon, L. and Micah, J. A. (2015). Pesticide Use Practices and Perceptions of Vegetable Farmers in the Cocoa Belts of the Ashanti and Western Regions of Ghana. Adv Crop Sci Tech, 3: 174. doi:10.4172/2329-8863.1000174.

Alex, G. (2007). Organic abundance report: fatally flawed-commentary. Renewable Agriculture and food systems (Cambridge: University press) 22(4): Pp321-323.

Andrew, W. (2007). http://disaster.itas.uft.edu/agrochemical security. htm agrow (538):5 retrieved 5th Dec. 2011.

Benedicta, Y. F., Paul, L. G. V. and Ahmad, M. M. (2010). Farmers' perception and adaptation to climate change: A case study of Sekyedu Mase District in Ghana. Tropentag, Zurich, September, 14-16.

Bhandari, S., Paneru, S.,Pandit, S., Rijal, S., Manandhar, H. K. and Ghimire, B. P. (2020). Assessment of pesticide use in major vegetables from farmers' perception and knowledge in Dhading district, Nepal. Journal of Agriculture and Natural Resources, 3(1), 265-281. DOI: https://doi.org/10.3126/janr.v3i1.27180.

Borno State Agricultural Development Programme (BOSADP) (2003). Borno State Agricultural Development Programme (BOSADP) Annual Report, Borno State of Nigeria.

Daura, M. M. (2001). The physical environment and development: A study of Borno region in environment and development issues in Sub - Sahara Africa. Seminar Series, Vol.1. Faculty of Social and Management Sciences, University of Maiduguri, Nigeria, Pp34 - 47.

Fleisher, G. (2006). Agricultural chemical- how much input is required, how much is too much. Agricultural and rural Sociology development, vol. 1. Pp51-53.

Funmilayo, O. K., Muhammad-Lawal, A., and Olawumi, I. G. (2016). Analysis of agro-chemical inputs use in maize production among Small-Scale farmers in Iwo local government, Osun state, Nigeria. International Journal of Agricultural Management and Development, 6(1), 43-50.URL: http://ijamad.iaurasht.ac.ir/article_520731_a137c912501920dc511a7e7e5a0fd593.

Idrisa, Y.L., Sulumbe, I. M. and Mohammed, S. T. (2007). Socio-economic factors affecting the participation of women in cooperative activities in Gwoza Local Government Area of Borno State, Nigeria. Journal of agriculture, Food, Environment and Extension, 6(2):72 - 78.

Jamala, G. Y. 1., Ari, B. M., Tsunda, B. M. and Waindu, C. (2013). Assessment of Agro- Chemicals Utilization by Small-Scale Farmers in Guyuk, Adamawa State, Nigeria. IOSR Journal of Agriculture and Veterinary Science (IOSR-JAVS) e-ISSN: 2319-2380, p-ISSN: 2319-2372. Volume 6, Issue 2 (Nov. - Dec.), PP 51-59 www.iosrjournals.org. 


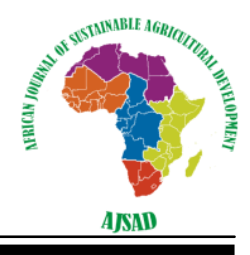

Matthews, G. A. (2008). Attitudes and behaviors regarding use of crop protection products- A survey of more than 8500 smallholders in 26 countries. Crop Protection, 27: 834-846.

Maisamari, J. Y (2001). Way of revamping agro-based industries in Nigeria. Retrieved from http//www.cenbankorg/out/publication/occational paper/od/2001/ow2e01.pdf.

Ngowi1, A.V. F., Mbise, T. J., Ijani, A. S. M., London, L. and Ajayi, O. C. (2007). Pesticides use by smallholder farmers in vegetable production in Northern Tanzania. Crop Prot. November; 26(11): 1617-1624.

Ntow, W. J., Gijzen, H. J., Kelderman, P. and Drechsel, P. (2006) Farmer perceptions and pesticide use practices in vegetable production in Ghana. Pest Manag Sci, 62: 356-365.

Onu, D. O. (2006). Analysis of the factors influencing farmers' adoption of alley farming technology under intensified agriculture in Imo State, Nigeria; using a qualitative choice model South African Journal of Agricultural Extension; Vol. 35 (2): pp. 158-175.

WHO (2012). Health and Environment Linkage Initiative, WHO. Toxic hazards.[Internet].

World Bank (2008). Agricultural innovation systems: from diagnostics toward operational practices. World Bank Washington, London. 